\title{
LEGAL DRAFTING IN THE OTTOMAN PERIOD
}

\author{
Meirison Meirison \\ Faculy of Ushuluddin,Universitas Islam Negeri Imam Bonjol, Padang, West \\ Sumatera, Indonesia, Jl. Prof. Mahmud Yunus Lubuk Lintah, 25153 \\ E-mail: meirison@uinib.ac.id
}

\begin{abstract}
Ottoman Turkey is a country based on Islamic Shari'a in which all cases that will decide must refer to Islamic shari'a. The door of Ijtihad has been closed for a long time, thus opening the opportunity for the authorities to issue legal decisions after being investigated by scholars. The design process is complicated because the books of fiqh do not instantly explain the laws required. The legal drafting process in principle based on the Qur'an and al-Hadith which are manifested by the mufti or Syaik al-Islam after being proposed by the sultan through the prime minister. After obtaining syaikh al-Islam's approval, the law or law is deemed legitimate. With a qualitative approach, the author conducted a literature study and analyzed the data collected and interpreted legal drafting during the Ottoman period. The decline of the Ottoman Empire in various fields has led to renewal including reforms in the areas of legislation, law, and justice which demanded legal codification in the form of majallah Al-Ahkam Al-Adliyah. This Majallah contains the law mu'amalah, which leads to ahwal As-syakhsiyah and serves to maintain Islamic law, which almost eliminated due to secularity that occurred.
\end{abstract}

Keywords:Legal drafting; Ottoman Period; Turkey

How to Cite:Meirison, M. (2019). Legal Drafting In The Ottoman Period. Jurnal Ilmiah Al-Syir'ah, 17(1), 39-53.

Permalink/DOI: http://dx.doi.org/10.30984/jis.v17i1.806

Copyright (C 2019, Jurnal Ilmiah Al-Syir'ah 


\section{INTRODUCTION}

The constitution has been around for thousands of years. Starting from the days of Ancient Greece, which can be proven by observing Plato's opinion that distinguishes the terms nomoi and political. Nomoi means law, whereas politicalimplies state. But at that time the constitution was still interpreted because it had not been made in a written text as it is known today.

In its heyday (between 624-404 BC) Athens once had no less than 11 constitutions. At that time, Aristotle as the largest student of Plato succeeded in collecting 158 laws from various countries so that he recognized as the first person to do comparative constitutional studies.

In Islamic society it was recognized, in the era of Rasullah, a written constitution was born known as the Medina Constitution, or some called it the Medina Charter. Although there is a debate about the term, experts like Philip K. Hitti, H.A.R.Gibb (2002) conclude the substance of its contents is a constitution. In Greek culture the use of the word UUD is closely related to the Resblica constituent saying that raises the slogan "Prinsep Legibus Solutus est, Salus Publica Supreme Lex" which means the king has the right to determine the state organization/structure because the King is the only legislator, so very absolute king power (2001).

In this condition, the Greek philosophers began their political thoughts, including Plato, Socrates, and Aristotle. In his book The Laws (Nomoi), Plato mentions that "Our whole state is animosity of the best and noblest life", Socrates in Panathenaicus and in Areopagiticus suggests "the politeia is the soul of the policy with power over it like that of the mind over the body ", both of which point to the understanding of the constitution (2001). Likewise, Aristotle, in his book Politics, relates our understanding of the constitution in the phrase "in the sense of life of the city" (2005).

In its development, the Romans who were widening the kingdom of the world, changed from a policy state (city-state), to become an empire (world empire) that could unite all regions of civilization in a kingdom. In Roman times, although constitutional science did not experience rapid development because, in Roman times more emphasis on practical issues than theoretical problems, but the right ideas in Roman times greatly influenced the development of the state in the following century. Some evidence among him (1977): First, in the event of a conflict between the patricians (nobles) and the Plebeians (the gossip, the commoners). This conflict can be resolved by a law known as the Law of 12 Tables. Second, the use of the term is Gentium was first used in Roman times to show that the Roman empire had distinguished the law for the Romans and outside of Rome. For the Romans ius civil was applied, whereas outside of Rome (not Original Roman) was implemented iusGentium (known as the law between countries). Third, the use of lex words was known in Roman times. Lex was understood as a constitution to determine how state buildings should be developed, which then becomes a keyword for understanding political and legal conception (1966). 
The idea of a constitution and constitutionalism in Roman times seen. However, the concept of constitutionalism is truly very unfortunate to disappear along with the defeat of the Romans by the Western European and European continents entering the Middle Ages (600-1400) (2011).

In the Middle Ages, the condition of European society was relatively conducive; at this time, a thinker named St. Thomas, who has the same thoughts as the forerunner of the Magna Charta. According to Thomas, state power is limited and subject to the law. The same idea also found in Ancient Greek thought but medieval times with the concept of God as the highest source of all authority, giving new meaning and a stronger basis for this principle. Thanks to a stable and unshakable stance, St Thomas and his ideas accepted in the Middle Ages. Then the views of St. Thomas are considered to correspond between human law and natural law and God's law (2015). This a better way for the country to institutionalize limited government. Furthermore, some of the ideas are stated in a written constitution and Judicial Review.

In the Middle Ages, the development of the constitution supported by the MonarchomachenSchool, which consisted mainly of Calvinist groups. This stream does not like the absolute power of the king. To prevent the king from acting arbitrarily against the people, the sect took an agreement between the people and the king. The covenant between the people and the king in an equal position produces a text called the Fundamentalist Leges, which contains the rights and obligations of each. The king can not only be held accountable but can also be fired even killed if necessary (2015).

This agreement between the people and the king is gradually written down in a written text. The purpose is so that the parties can easily find out their respective rights and obligations. Also, it is easier for one party that feels aggrieved to sue the other party who violates the agreement.

The agreement that contained rights and obligations could also occur between the king and the nobles. The nobles have the right to ask the king for protection. Meanwhile, the king has the right to ask for help from nobles in the event of a war. Even agreements can be made between people before there is a country. In the history of the colonists who headed for the Americas, they agreed while still on the ship "Mayflower" (2001).

Initially, the constitution was intended to regulate and limit the authority of the authorities, guarantee the rights (rights) of the people, and regulate the government. Along with the rise of nationalism and democracy, the constitution is also a tool to consolidate political and legal positions by monitoring life together to achieve ideals. That is why in the present era the structure does not only contain the rule of law, but also formulates the principles of law, the direction of the state, and the standard of policy which as a whole binds the authorities.

In the Middle Ages, there were several terms used in Roman times whose substance inspired regulations in the country in the following period. 
For example, there is a legal codification, namely a statutory codification organized by the king, called Corpus Juris, and the codification carried out by Pope Innocentius, a regulation issued by a church called Corpus Juris Connonici. The most crucial thing in this writing is Corpus Juris, which consists of four parts (2001): Institutes, this is teaching but has binding powers such as the Act, if in the Law something concerning there is no regulation, then the regulation concerning this can be seen on the Institution. Pandecten, this is just the interpretation of scholars towards management. Codex, this is a regulation or law stipulated by the government/authority; Novellen, this is an addition to a statute or rule.

Next, the constitution is the most essential and primary source of law for the country. In modern times, almost no country has no structure. Thus between the state and the structure are two inseparable institutions. The purpose of this article is to: To study the process of constitutional change in Turkey; Analyze the operation of the collapse of the Ottoman Caliphate in the field of the rule of law; Studying Ottoman Relations militarily, socially, economically and legally with the countries around them related to legal issues and their implications.

The Ottoman state is a state based on the constitution, which refers to the Qur'an and Hadith as the primary legal source and interpreted by the scholars of the Hanafi school. After it has been approved and approved by the sultan to be socialized and practiced by the initial instructions ministers and governors as well as religious judges in regions in the Ottoman province, after a diplomatic friction with the West, especially France, which had been friction only through crusades, had a negative impact on the application of Islamic law in the Ottoman region and eroded little by little, the government began to neglect Islamic law and cancel it for the sake of footpath in accordance with the Word of the Prophet "you will imitate infidels like a monitor lizard into the hole little by little". Thus the sultans and scholars themselves narrowed down the lives of Muslims in the Ottoman region which ended in the collapse of the Empire after 600 years in power in the several areas on three continents (1988c).

Based on the arguments above, it is necessary to know about the process of shifting legal drafting rules in the Ottoman Empire, because so far there has been no process of codifying the standard law, which recorded in the form of standard practices, the cause of the legal drafting process ?; Does the codified law cover all cases of Islamic law ranging from criminal, trade, family law ?; how did Kemal Ataturk cancel Islamic law in Turkey, and change it into a secular state so easily?

\section{RESEARCH METHODS}

In discussing this issue, the author conducted a literature study by reviewing books, papers, and manuscripts related to legal drafting during the Ottoman period. By making a comparison with the literature written by the West, the author analyzes and gets findings in this problem. The author does the logic of deductive thinking in the field of legal history; the author explains the issues of cases of court decisions, which then lead to the 
conclusion of the ruler at that time. By collecting resources and verifying the source whether it comes from sources written by historical actors that can be used as primary sources. The next step the author interpreted the events related to legaldraftings, such as judicial capitulation, torture, and infiltration of Western laws into Ottoman Turkish jurisdiction. This research is qualitative research, which based on policies taken by Ottoman rulers in the field of law along with other governmental systems. The author tries to give a historiographic picture of the results of the study based on deductive logic.

\section{RESULTS AND DISCUSSION}

In the following period, the Ottoman empire which based on the Shari'at of Islam began to shift to secular law, this occurred at the end of the 19th century, precisely in the Tanzimat era (1839-1876) to be a big question mark because basically, this change could not come up with suddenly. Does the one carry an emporium that was standing upright with authority change slowly the existing laws in his country? Era tanzimat is a renewal movement that took place in the Ottoman Empire, which essentially corroborated the efforts of the Ottoman government to make improvements in the rules of law in all fields, and one of the legal codices compiled by Majallah alAhkam al-Adliyahi (1876 AD) in addition Charter of Gulhane and Humayun (2000). To find out more about the development of Islamic law in the Ottoman period this simple paper tries to describe, with the subject matter of discussion; A glimpse of the Ottoman Turks, Before Tanzimat, Era Tanzimat, Majallah al-Ahkam al-Adliyah and after tanzimat (1985).

The State of the Ottoman Empire is a multiethnic country, which for centuries dominated the balance of military, political, and legal power in Europe (1988a). The Ottoman Empire has become a symbol of the power and supremacy of law in the Islamic world and Europe, many events and agreements have been carried out and the preparation of bilateral and French and multilateral rules with Russia, Britain and Western European countries. This country is closer to the term empire because he had replaced the position of two kingdoms at once, namely the Persian and Eastern Roman empires (Byzantium) and Western Rome (2005).

The country's jurisdiction includes almost all Arab countries except Morocco, Azerbaijan, Cremia, the Caucasus, Armenia, Serbia / Bosnia, Bulgaria, Romania, and Greece. All had been brought under Islamic legal control, which finally rose to the throne of an intense and violent Sultan named Sultan Salim, in England he was known as Selim the Grim (who was always sullen). He wanted to force the entire population of ethnic groups in the Ottoman region to be Muslim and use Arabic as the official language of the country, including the inhabitants of Eastern Europe, but this was opposed by the ulama, who eventually submitted to the ulama's decision. It means that the Sultan does not have absolute power in making decisions, which must refer to syara law 'as the fundamentalrequirements stated in the Qur'an and Hadith if they were not listed in them both then interpreted (ijtihad) by the scholars. 


\section{A BRIEF HISTORY OF THE OTTOMAN TURKISH CONSTITUTION}

Religion in the Turkish tradition has a significant role in the social and political field. Society is classified according to faith. The kingdom itself is very tied to the shari'ah so that the ulema's fatwa becomes the applicable law. Therefore ulama have their place and play a significant role in the kingdom and society. Without the legitimacy of the mufti, the decisions of the royal decree cannot work (1999). Licensed products in the Ottoman Empire based on the Ijtihad of the previous and later ulama who referred to the Hanafi school of thought.

The method used in establishing the law (istinbath) based on seven main points:Al Quran as the source of all legal sources; The Sunnah of the Prophet as an explanation of the things that are global in the Qur'an; Fatwa of a friend (Aqwal Assahabah) because they all witness the descent of the verse and know the asbab nuzul and the asbabul khuruj of the hadith and the narrators. While the fatwa of the tabiin has no position as the fatwa of friends; Qiyas (Analogy) which used if there are no sharia texts in the Qur'an, Hadith and Aqwal Asshabah; Istihsan that is out or deviating from the necessity of logic towards another law that blames it because it is not precisely Qiyas or Qiyas that is contrary to Nash; Ijma 'that is the agreement of the mujtahid in a legal case at a particular time; Urf is the custom of Muslims in a specific problem that has no texts in the Qur'an, Sunnah and there is no practice in the days of friends. Great works left by Imam Hanafi, namely Fiqh Akhbar, Al 'Alim Walmutam and Musnad Fiqh Akhbar. These books are a reference to the positive draft law that applies to the Ottoman state.

\section{LEGAL PROCESS FOR TURKISH OTTOMAN DRAFTING}

In Turkish work, the formation of draft laws came from the understanding of the Koran and the Prophetic Hadith, and the fatwas of the companions of Rasulullah also taken into consideration. If you don't get any information related to the problems that occur in the field, then qiyas/analogies and istihsan are used, (legal exceptions), as well as customary and cultural behavior in the community where the law will be applied. The draft law or law was given to the Sultan and approved or not approved to make into new rules and regulations. Likewise, if the sultan wants to make a regulation, it must be discussed first with syaikh al-Islam and the ulama assembly in Istanbul if it is approved, then the draft law and management will be socialized by the prime minister to various government agencies at the center or province. Without the approval of Syaikh Al-Islam, the code does not work.

\section{FOREIGN CAPITULATION}

The foreign capitulation was a blow that caused severe injuries to Ottoman Turkish legal institutions and Muslims in general. Europe has not been able to defeat it by military force so that by shifting Islamic law little by little, it is an active effort to eliminate the effects that have been behind 
the Ottoman authorities and society. Initially, this capitulation was given to several countries for trade and political purposes. Capilutation brings undesirable results, including the loss of legitimacy of state law that has been valid since the founding of the country where Uthman Khan was appointed to leadership on 27 July 1299 AD He vowed that the Ottoman constitution was the Qur'an and Sunnah Prophet SAW (2018).

After all the legal designs regarding foreign capitulation completed, gradually began to be applied which made the Ottoman state which had been entirely in control of its territory legally began to give up its rights, the loss of national honor, with the waning application of God's law towards Muslims which ended in collapse the Caliphate itself, defeat in the war, foreign interference in domestic affairs due to the capitulation had become the leading cause for the failure of the glory of Muslims who had had this protector the Ottoman Empire (Emrah Sahin, 2019).

An awareness that arrived late during the caliph Muhammad Rasyad in $1914 \mathrm{AD}$ all forms of capitulation were canceled, but the related foreign countries did not admit it even their troops were everywhere to preserve and guard the consuls in the Ottoman region. In 1922 AD, the Treaty of Lausanne was held. The Turkish State was removed from all foreign capitulation agreements, but the Turkish and Arab territories were divided into small immersed states which had been unofficially occupied by European countries. On October 14, 1949, all of the foreign capitulations ended, this would still not be something of value for Turkey, the Islamic state was gone, collapsed in 1924, a chaotic economy, at that time there was no more Western countries wanted for resources nature that is owned by Turkey, moreover Russia has ruled the Black Sea and the Caspian Sea which are full of oil content around the lake (1988b).

\section{CHRONOLOGY OF FOREIGN CAPITULATION}

In the time of Sultan Bayazid Khan II, diplomatic relations began with foreign countries such as Russia, after the Russian empire split into small kingdoms, most of which were controlled by the Mongols. Duke Moscow named Ivan tried to take his territory back little by little so that he needed peace with his neighboring countries, especially the Ottoman Turks. Relations began in 1481 and continued with the sending of envoys to Istanbul in 1492, which brought many gifts from the Russian Emperor. In 1492 was granted trade rights and special rules in the form of a law from the Ottoman Empire for the benefit of Russia in trade in the Ottoman region. Diplomatic relations have also opened with the Polish kingdom. An agreement was held between the two countries in $1490 \mathrm{AD}$ and renewed in 1492 AD. However, the relationships between the two countries became cloudy because both of them wanted a Romania / Transylvania region (Emrah Sahin, 2019).

In $1525 \mathrm{AD}$, the King of France sent his ambassador to Istanbul named Jean Frank Geovani (1994), he appealed to Sultan Sulaiman to take over the Magyar (Hong Kong) region. Hong Kong is Germany's most powerful ally. Regional, military and geographical information are given to 
the Ottoman authorities. In February 1536 came a messenger from France named Mesio Jean de La Pour (1988c). Either because of his expertise in diplomacy which made him succeed in making a deal that was not of much concern to the Ottoman Empire (1992), along with this agreement France also gained space from the pressure of the Holy Roman Empire, emperor Charles Quint. Because Sultan Sulaiman succeeded in taking the territory of Hong Kong and had pounded on the gates of the city of Vienna, the capital of Austria (2014). The contents of the agreement include (1988c):

Paragraph 1. Both parties entered into a contract which both represented the sultan and the king of France. For peace and the lifelong MOU of the two rulers, this rule applies to all regions and vassal (countries that are under protection / under protectorate) both countries. Fortresses, cities, civil and military ports, oceans, islands, and all the territories which were conquered by the two countries lately, were permitted for residents of both states to travel by sea and military ships, both sea, and land on the territory of the two countries. Returning to the port and city to trade, given to them the freedom to carry out activities without any pressure on them and their merchandise.

Paragraph 2. Residents of both countries are allowed to buy and sell any goods that not prohibited from being traded; they may transport them by sea and land from one country to another after paying the applicable taxes on both countries by applicable regulations without paying anything outside of charge (wild levies).

Paragraph 3. When a Consular has been appointed by King Peranjis in Constantinople to know in Pierre (Greece), Alexandria (Egypt) then he is treated properly, he must be heard and punish all criminal cases both civilian and military-related to French society willbe held with French law without any pressure from the Shari'ah Judge on the territory of the Ottoman Empire. If French citizens who do not obey the French consul in settling cases should be assisted by Syariah judges and security forces to be paid in French law, if they ask for justice in the Shari'ah judges and establish Islamic law, then the law is canceled or invalid.

Paragraph 4. It is not permissible to process complaints filed by the Turkish nation or tax collectors on the French nation in Turkey, whether they are civilians or civilians from France, as long as the party who filed the case does not have strong evidence / bonds that written in the hand of the defendant or the official reason comes from the shari'ah court or the French consul if complete evidence of a complaint is not heard without an interpreter appointed by the consul.

Paragraph 5. The Shari'ah Judge or the Ottoman government apparatus must not listen to complaints of crimes committed by the French nation in Ottoman territory. Based on complaints filed by the Turkish nation, or the tax collector will still be a Shari'ah Judge or an authorized official took the defendant to the place of Sadr A'zam (prime minister), if the incident took place outside the city of Istanbul then this case was 
brought to the highest employee in the region, wherein the tax collector's testimony could be accepted.

Paragraph 6. may not process judging cases carried out by French warriors and their servants and assistance relating to religious matters in front of Judge Shari'ah or Sanjaq (Head of Regency Government) the court conducted in front of the Palace. They are permitted to carry out their religious rituals; they may not be forced to convert to Islam or be considered Muslim, as long as they have not declared themselves to convert to Islam.

Paragraph 7, if there is a transaction between the population of France and Turkey in the territory of Turkey, the Frenchman is in debt, and then he returns to France without paying his debt, the French consul is not responsible for his debt, or his brother or other Frenchman. The King of France is not liable for these debts, but if he has goods that can be confiscated, his rights can be taken anywhere both in the Ottoman region and in the territory of France.

Paragraph 8, may not use or manipulate French merchants or their servants or their ships and their logistical equipment or their merchandise forcibly for the benefit of the sultan and others, both facilities owned at sea and land, except voluntarily and with permission from the owner.

Paragraph 9, French merchants and people who are in the territory of Turkey have the right to use all the facilities they have and have their inheritance before they die, their property is distributed according to the will they leave behind, if they are not intellectually their property is intended for experts the inheritor or his representative with the consul's knowledge, if there is no consul, the Shari'ah Judge saves the property accompanied by a witness. If the consul is there, the Judge or the authorities are not entitled to protect the property; if the asset is already stored in the treasury of the Ottoman state, then the property must be submitted to the consul if the expert asks the consul the consul's obligation to hand over the property.

Paragraph 10, by holding the Sultan and King of France under this agreement, all people of both countries in the two regions of the country, whether they are on land voyages or voyages, are either cultured or slaves caused by war or bought and sold released from slavery and confinement as respectable human beings, it is done solely with reports of consuls or ambassadors, this can be done if they convert to religion the release of slavery is still carried out. From now onwards the Sultan and King of France, commanders, admirals, or other personnel under the two countries or hired people may not buy or detain prisoners of war to be used as slaves even though they are carried out by pirates in the region the two countries should not carry out the seizure of their property, if that happens then the perpetrator must be punished for violating the peace agreement of the two countries, the goods seized must be returned to the owner if there are privileges for the perpetrator. They have carried out guaranteed by the commander in chief / syaikh al Islam and great law (France). 
Paragraph 11, if the two countries find a foreign ship, this ship must lower its anchor, and raise the flag of its state so that its identity is known, this ship may not be detained or intimidated by the two countries' armed forces. And the damage. If the fleets of the two countries meet, they must notify them with cannon fire, and ask the captain of the ship their identity and may not forcefully inspector put pressure on the boat.

Paragraph 12, if a French ship comes to one of the ports of Turkey, logistics should be given at a reasonable price without having to empty the cargo ship, then the boat is allowed to sail anywhere. If the boat arrives in Istanbul and wants to travel after being inspected and getting permission to leave the tax officer, the boat may not be inspected elsewhere except in front of the Dardanelles strait fortress without paying anything.

Paragraph 13, if the ship breaks out or sinks in the territory of the two countries accidentally, the crew of the survivors still get their independence, the items must not be taken. If all crew members die then the goods obtained are left to the consul, the captains, tax officers, shari'ah judges or state officials are not entitled to take the products in the slightest, if that happens then, the perpetrators must be severely punished. State officials must help smooth the delivery of these items.

Paragraph 14, if the slaves belonging to the Turks fled to the house of a Frenchman, the Frenchman should not be interrogated, all he could do was check the home and the vehicle and his ship. If the slave obtained, then, the Frenchman could only be punished by the consul.

Paragraph 15, if a Frenchman who lives in the territory of Turkey for less than 15 years does not pay any taxes and is not permitted to work in an arsenal or other work, so are the Ottoman residents in the territory of France. The King of France also included the Pope, King of England, and his brother King of Scotland included in this agreement, the agreement on these countries took effect after eight months later.

Paragraph 16, the two rulers sent the agreement document to all regions and officials who were there after six months of the announcement, then the treaty law of the two countries took effect. There is no reason not to know about the agreement after six months the agreement socialized on the territory of the two countries, including in Alexandria, Egypt, Lucilia, Norbone and all regions of the two countries. Finish the deal.

Something hard to believe, the Ottoman Empire entered into an agreement that actually benefited its old enemies in a crusade that lasted hundreds of years, since the time, the Saljuk Turks, Salahuddin al-Ayubi. This agreement happened after the Ottoman Empire came to power in Europe and was at its peak the power that no country in the world at that time was able to conquer. This agreement has demeaned the dignity of the Ottoman Turks and Muslims and has canceled some items from Islamic law itself in the treatment of Islamic countries against non-Muslims who are in the Islamic region (1994). It may be because of diplomacy; even some 
historians say this is a plot and deception against a Sultan who has fallen asleep with vast wealth, women, and power.

Thus France was the only country that held trade, diplomatic and legal freedom in the Ottoman Empire. This agreement is the cause of foreign intervention that will destroy the work of the Ottoman Empire in the future, France is a member of the crusade that has long waited for the opportunity to take control of Palestinian land and the Middle East. But for the time being, it cannot be done with military force.

\section{LEGAL CODIFICATION AS IMPACT OF CAPITULATION}

\section{Ahkam al-Adliyah magazine}

The Reformation Movement (Tanzimat) was carried out, during the time of Sultan Abdulmejid I and Abdulaziz (1839-76). The pretext is renewal and modernization. There are severalessential elements from this Tanzimat, which is nothing but the termination of the law of Muamalat, replaced by secular law. First, the doctrine of equality for non-Muslims was adopted, which resulted in the elimination of jizya, namely, head tax for non-Muslims (1839). This became the door to many things: the abolition of the dhimmi law (1857), land ownership permits for foreigners (1867), the introduction and application of the secular justice system, Nizamiye (1869) replaced the Islamic court and printing of paper money when Istanbul was declared bankrupt (1876 ). Before all that, in 1826, the previous government, Sultan Mahmut, had been forced to dissolve the 'Jihad Army', the Janissary; separating Islamic and secular education, and adopting a secular European way of life. In the chaos of the Tanzimat the Nizamiye judges experienced many problems in the field, for holding on to Civil Law (1850) and the new Commercial Law (1861) which referred to secular law adopted from Europe (Switzerland) (Fatma Çalık Orhun, 2019). They don't understand the requirement of muamalat. So, a Yuris Commission was formed, with the mandate to codify the law of muamalat which had been valid for centuries, but scattered about. The result is a book on Islamic Civil Law, entitled Mejellle Ahkame Adliye. It is a law of sale and purchase/financial transactions originating from the Hanafi school, because the official school of this State is the Hanafi school, although there are also several schools within it. The most dominant cause of the compilation of this book is when a secular court established because the capitulation has not been empowered to carry out the judicial process. Like a person who has gout that is swollen and then needs a stick, after he was healed, he no longer needs it and then throws away the rod. District courts were established throughout the Ottoman region, shifting the Islamic Shari'a court. The new judges received instructions from religious judges who had experience in resolving problems in all fields. The Chief Judge also implied assistance to spiritual judges in adjudicating and deciding cases at the Cassation level. They are still confused because, in Islam, there is no appeal; each case is decided in one court and will not move from one judge to another (2001). Facilitate the judges and supreme justices to study the problems and laws of transactions and international trade, this book was prepared (2018) and became an official reference in the field of mu'amalah. The clerical 
codification of the law was formed in $1869 \mathrm{AD}$, they collected bills originating from the Hanafi school of thought and then took the most suitable and most robust truth according to the committee (2017). Mejelle is by imported legal material originating from Europe so that it is easily understood by the judges who just studied earlier. In 1851 the codification of the law was born, named Mejella Ahkem Edliye (2000).

This magazine also contains the article about the rules of fiqh (2014). In 1876 in the month of Sya'ban, the decree of the Sultan Abdul Aziz Khan ibn Mahmud was issued after the legal socialization implemented. So be Mejelle is a general civilian enough that comes from the Hanafi school of fiqh law (1990). In the year 1801, it was said that a mujtahid must appoint as the reference for all requirements. The judges must refer to the mujtahid, and if there are differences of opinion and perceptions with mujtahid, then the code decided by the judge is invalid. With such an immediate aversion to dissent in figh, it can be muted, but it is also unfortunate that the book does not benefit from other school books (2017).

\section{Mejelle Points}

Mejelle Alkahme Adliye was completed in 1869, completed in 1885, during the time of Sultan Abdul Hamid II, the last sultan to try to reestablish Islamic law. Mejelle has been translated into Arabic (Majallah AlAhkam-i-Adliya), English (The Mejelle and A Complete Code of Islamic Civil Law) and Malay in the state of Johor, Malaysia, which has become a legal reference, since 1913 (Magazine Ahkam Johor). In Turkey itself, although the secular civil law system was increasingly gripping, Mejelle continued to apply until 1926, two years after the official end of the Ottoman Empire (2010).

Mejelle is a vast legal system of muamalah, except for family law which consists of munakahat (annihilation) and pharaid (inheritance), which are arranged separately in another book, Huququl Aila (arranging marriage matters). This modification consisted of sixteen (16) books, twelve books regulating commercial affairs, and the last four books arranged the final questions about dispute resolution and litigation procedures (Sulh and Ibra') (2015).

The Book I, about Trade (Buyu'). Then several problems regarding renting (Book II Ijarah), about guardianship (Book III Kafalah), transfer of debt (Book IV Hawalah), and mortgage (Book V Rahn). Some books then arrange safekeeping questions (Book VI Amanah), grant questions (Book VII Grant), about Cheat and Destruction Actions (Book VIII Ghasab and Itlaf), then questions about prohibition, coercion, and warnings (Book IX).

Then one book arranges business cooperation questions consisting of two forms of trade union and investment (Book X Syirkat and Mudarabah), followed by agency questions (Book XI Wakalah). The last four books include a matter of compromise (Book XII), an issue of recognition (Book 
XIII), a claim or indictment (Book XIV), evidence and oath (Book XV), and finally the duties and authority of the judge (Book XVI).

Overall Mejelle contains 1851 articles (English edition, 379 pages) (2014), preceded by articles on general provisions, both for each Book, as well as Mejelle's Introduction itself, which contains the legal principles and rules (qawaid) that apply, consists of 100 articles. Mejellealso equipped with an alphabetical glossary. The number of items governing transactions on the market is the most numerous. Book I concerning trade, for example, consists of 300 articles, while book II on leasing-self consists of 207 items.

\section{CONCLUSION}

The legal drafting process in the Ottoman period focused on starting with the sultan's desire when faced with nonexistent problems listed in the Islamic Shari'a or fiqh opinions from Hanafi-based jurists. The door to ijtihad has been locked due to the lack of the jurists who are skilled and reach the degree of mujtahid so that new legal products which are released from the realm of fiqh are emerging. At least the legal designs and products have been reviewed by Syaikhul Islam so that they do not conflict with the Islamic Shari'a before the laws and laws are implemented in the courts and trade activities. The occurrence of Tanzimat has made this legal drafting activity even higher with the compilation of Majallah al-Ahkam al-Adliyah so that the Islamic Shari'ah is not completely excluded from the life of the Ottoman people who have been depressed with foreign capitulation agreements. So it was formed: the Bureau of Syaikul Islam (1924); the sharia ministry; Sharia court; and the Consul Court and the Mixed Court.

\section{ACKNOWLEDGMENTS}

The author expresses gratitude to the Rector, Dean of the Faculty of Ushuluddin, and all academic members of Imam Bonjol State Islamic Uneversity Padang who have supported and supervised to complete this article. The next appreciation is expressedto the members of the Editorial Team of Al-Syir'ah Scientific Journal of State Islamic Institute of Manado who have helped to publish this article.

\section{REFERENCES}

Al-Ghazâlî,Muhammad bin Muhammad Abu Hâmid, (n.d.).Al-Mushtashfâ fî Ushûl al-Fiqh, Volume. 3, Madinah: al-Jami'ah al-Islamiyyah alMadinah.

Ali, Hasan, (1996). Masail Fiqhiyyah: Zakat, Pajak, Asuransi dan Lembaga Keuangan, Jakarta: Raja Grafindo Husada.

Al-Jauzi, Ibn Qayyim,(1977), I’lamul Muwaqi'in, Volume 2 Beirut: Dar alFikr. 
52

Al-Kilânî, Abd al-Rahmân Ibrahîm, (2000). Qawâ'id al-Maqâshid 'inda alImâm al-Shâthibî: 'Aradhan wa Dirâsatan wa Tahlîlan, Damshiq: IIIT.

Al-Muqrî, Ahmad bin Muhammad bin Alî al-Fâyûmî,(1987).Al-Mishbâh alMunîr fî̀ Gharîb al-Sharh al-Kabîr li al-Rafi'î, Libanon: Maktabah Lubnan.

Al-Qarafi, Syihâb al-Dîn,(1307 H).Syarh Tanqîh al-Fusûl fi Ikhtisâr alMahsûl fi al-Ushûl, Kairo: Al-Matba'ah al-Khairiyyah.

Al-Qardhawi, Yusuf, (2006).Dirasah fi Fiqih Maqâshid Syari'ah: Baina alMaqâshid al-Kulliyyah wa an-Nushush al-Volume'iyyah, Kairo: Dar as-Syuruq.

Al-Râzi,Fakhruddîn Muhamad ibn Umar ibn Husain,(n.d.).Al-Mahshûl fì 'ilm Ushûl al-Fiqh, Volume. 2, Saudi Arabia: Maktabah alArabiyyah al-Sa'udiyyah.

Al-Sa'dî, Abd Hâkim Abd Rahmân As'ad, (n.d.), Mabâhis al-'Illat fì alQiyâs 'inda al-Ushuliyîn, Beirut: Dâr al-Bashâ'ir al-Islâmiyyah.

Harahap, Syabirin, (1984). Bunga Uang dan Riba Dalam Hukum Islam, Jakarta: Pustaka al-Husna.

Hasan,Ahmad,(1986),Analogical Reasoning in Islamic Jurisprudence, Islamabad: Islamic Research Intitute Press.

Jamil, Fathurrahman,(1995). Metode Ijtihad Muhamamdiyah, Jakarta: Logos.

Kasmir, (2008). Bank dan Lembaga Keuangan Lainnya, Jakarta: RajaGrafindo Persada.

Marzuki, Peter Mahmud, (2005). Penelitian Hukum, Jakarta: Kencana.

Muathahari,Murtadha,(1984). Perspektif Al-Qur'an Tentang Manusia dan Agama, diterjemahkan oleh Haidar Baqir. Bandung: Mizan.

Muhammad, (2000). Lembaga-lembaga Keuangan Umat Kontemporer, Yogyakarta: Multi Karya Grafika.

Nujaim,Ibn, (n.d.).Al-Asybah wa al-Nadhâ'ir, Beirut: Dar Kutub alAlamiyah.

Sjadzali,Munawir,(1997). Ijtihad Kemanusiaan, Jakarta: Paramadina.

Sunggono, Bambang, (1997). Metodologi Penelitian Hukum, Jakarta: Rajagrafindo.

Tohari, Chamim, (2016). Argumentasi Ibn Hazm: Dekonstruksi Kehujjahan Qiyâs Sebagai Metode Penetapan Hukum Islam, Jurnal Istinbath, Volume 13 No. 1, Mei.

Umar, Umar bin Shâlih bin, (2003). Maqâshid al-Sharî'ah 'inda al-Imâm al-'Izz bin 'Abd al-Salâm, Urdun: Dâr al-Nafâ' is li al-Nahr wa alTawzi..

Zuhaili, Wahbah,(1989).Fiqh Islam wa Adillatuh, Volume 4, Damaskus: Dar al-Fikr.

Zuhdi, Masjfuk,(1998). Masail Fiqhiyah, cet VIII, Jakarta: Surya Grafindo. 
Jurnal Ilmiah Al-Syir'ah Vol. 17, No. 1 (2019): 39-53

Website: http://journal.iain-manado.ac.id/index.php/JIS

ISSN 2528-0368 (online) ISSN 1693-4202 (print)

Zysow,Aron,(1984). The Economy of Certainty: An Introduction to the Typology of Islamic Legal Theory, Massachusetts: Harvard University. 